(REVIEW ARTICLE)

\title{
Nutritional quality and use of whey in human food for its valorization
}

\author{
Roseline T. M. Bleoussi 1, ${ }^{*}$, Christian T. R. Konfo 2, 3, Célestin C. K. Tchekessi 1, Pivot A. Sachi ${ }^{1}$, Jultesse S. B. \\ Banon ${ }^{1}$, Anayce A. Djogbe ${ }^{1}$, Karl T. Assogba ${ }^{1}$, Dahouenon-Ahoussi Edwige ${ }^{2}$ and Bokossa Yaou Innocent ${ }^{1}$ \\ ${ }^{1}$ University of Abomey-Calavi (UAC), Faculty of Sciences and Techniques, Laboratory of Microbiology and Food \\ Technology / Research Unit in Food Safety (URSSA), 01 PO BOX: 2009 Cotonou, Benin. \\ 2 University of Abomey-Calavi (UAC), Polytechnic School of Abomey-Calavi, Laboratory of Study and Research in Applied \\ Chemistry, 01 PO BOX: 2009 Cotonou, Benin. \\ ${ }^{3}$ National University of Agriculture (UNA), Schools of Science and Techniques for Preservation and Processing of \\ Agricultural Products, PO Box114, Sakété, Benin.
}

Publication history: Received on 23 September 2020; revised on 26 October 2020; accepted on 28 October 2020

Article DOI: https://doi.org/10.30574/wjarr.2020.8.1.0356

\begin{abstract}
Whey is generated during cheese making and can be up to nine times the weight of cheese. The objective of this work is to highlight the nutritional quality and the importance of whey in order to explore other ways of valuing it in human food with a view to improving the nutritional quality of locally processed foods in Benin. To achieve this goal, a literature review was carried out between January and September 2020. The results revealed that whey contains more than $90 \%$ water. It also has a high content of lactose (75\% of the dry matter), a low content of fat, soluble milk proteins (approximately 20\% of total milk proteins) and various minerals. It also contains other components, such as citric acid and lactic acid, non-protein nitrogenous materials such as urea and uric acid and group B vitamins, mainly vitamin B1 (thiamine), vitamin B2 (riboflavin) and vitamin B6 (pyridoxine). Whey is exploited indirectly through its constituents in the food and pharmaceutical industry and also directly through the production of some variants of cheese.
\end{abstract}

Keywords: Cheese; whey; nutritional value; valorization; Benin

\section{Introduction}

Milk is produced and consumed in virtually every country around the world and ranks among the top five most important agricultural commodities, both in quantity and value. In 2013, with a total production of 770 billion liters valued at US \$ 328 billion, milk ranked third in the world for agricultural raw materials in terms of production volume and first in terms of value [1]. Milk contributes $27 \%$ to the added value of livestock and $10 \%$ to agriculture.

The high perishability of milk linked to its composition remains the greatest constraint for its production. The transformation of milk into dairy product of which cheese constitutes an alternative to improve its shelf life on the one hand and on the other hand to increase the income derived from its production.

The production of cheese generally consists of the coagulation of milk by enzymes and / or lactic ferments and then the draining of the curd. Whey is the liquid obtained after the separation of casein and fat during the coagulation of milk. Formerly considered as waste from cheese production, whey is now considered as a by-product. Representing at least $85 \%$ of the milk transformed into cheese, the valuation of whey is both an economic and ecological issue [2].

\footnotetext{
${ }^{*}$ Corresponding author: Roseline T. M. Bleoussi

University of Abomey-Calavi (UAC), Faculty of Sciences and Techniques, Laboratory of Microbiology and Food Technology / Research Unit in Food Safety (URSSA), 01 PO BOX: 2009 Cotonou, Benin.
} 
The whey industry has grown tremendously in recent years in developed countries. The stimulation of this development is linked on the one hand to the enormous potential for pollution caused by this product and on the other hand to the fact that the majority of its dry matter contains elements with high nutritional value [3]. Due to its richness in nutrients such as lactose, soluble proteins, water-soluble vitamins, minerals and fat, whey constitutes an excellent culture medium for microorganisms, which makes this product a formidable pollution factor [4, 5].

Whey has been used in alternative medicine since Hippocrates. It is a concentrate of serum proteins very interesting from a nutritional point of view. Due to its low concentration in fat and conversely, its high concentration in proteins, the first users of whey concentrate were bodybuilders and those who practice bodybuilding. Whey indeed offers a significant protein intake without fat with the bonus of optimizing the synthesis of muscle mass and rapid recovery in case of micro tears.

The nutritional qualities of whey, however, go far beyond simple sports use. We have thus noticed that the consumption of whey allowed to increase the effectiveness of chemotherapy to treat cancer, to proactively protect against certain bacteria and viruses, and that in general, this significantly increased the efficiency of our immune system even in case of immunodeficiency (hepatitis B, AIDS, etc.) [6]. Finally, concentrated whey helps fight stress and improves cognitive functions.

Fresh whey, in liquid form, is not easily recovered for human consumption and is therefore hardly used in this form. In developed countries several high added value products have emerged since 1970 in a concentrated and fractionated form of this whey. This is particularly the case with proteins, thanks to their technical-functional and nutritional properties which are particularly interesting in the food industry [7].

Despite its low level in breeding, the consumption of milk and dairy products is experiencing a considerable boom in Benin today. Peuhl cheese is one of the main milk processing products in Benin. However, the whey resulting from this transformation is almost unknown and unused. The objective of this work is to highlight the nutritional quality and the importance of whey in order to explore other avenues of its valorization in human food in order to improve the nutritional quality of processed foods in Benin.

\section{Typology and production of whey}

Coagulation is the first step in turning milk into cheese. It results in the formation of whey and a gel called the curd which is the basis of cheese making. Coagulation is carried out by three routes (acid route, enzymatic route and mixed route) leading to two types of whey: that resulting from the coagulation of non-acidic milk, by rennet, and which is called "sweet whey" and that resulting, from the production of fresh, soft cheeses or lactic casein called "acid whey" (Tabeau.1) $[8,9]$.

\subsection{Acid whey}

Obtained after the coagulation of milk by precipitation of caseins at their isoelectric $\mathrm{pH}$ of 4.6 by adding strong acid or lactic acid [10]. Casein is combined with calcium salts, acidification leads to its demineralization which causes a large proportion of mineral elements, especially calcium and phosphorus, to pass into the serum [11]. Acid whey is less rich in lactose and richer in minerals. They are also more inoculated with lactic germs and less subject to fermentation than sweet whey [3]. The high levels of lactic acid and minerals pose difficulties for dehydration; also acidic whey are often used in a liquid state while sweet whey are generally dehydrated [3]. Acid whey comes from the manufacture of fresh pasta and soft pasta, its $\mathrm{pH}$ varies between 4.5 and 5 [12].

\subsection{Sweet whey}

Sweet whey is obtained after the coagulation of casein under the action of rennet without prior acidification, a mild serum is then obtained, poor in mineral salts and rich in lactose and proteins. In addition to soluble milk proteins, this type of whey contains a glycoprotein which comes from the hydrolysis of Kappa casein by rennet [13, 9]. When cheese whey is not treated with all the necessary precautions, the continuation of natural fermentation increases its acidity. Sweet whey from the manufacture of cooked or uncooked pressed cheese, has a pH varying between 5 and 6.3 .

The manufacturing processes of the different types of whey are summarized in Figure 1. 
Table 1 Different types of whey.

\begin{tabular}{|c|c|c|c|c|}
\hline Types & Acidity degree & pH & Origins & References \\
\hline Sweet whey & $<18^{\circ} \mathrm{D}$ & $6.5-6.7$ & $\begin{array}{l}\text {-Pressed cheese } \\
\text { - Cooked cheese dairy } \\
\text { - Rennet caseinery. }\end{array}$ & {$[14,15]$} \\
\hline Acid whey & $>18^{\circ} \mathrm{D}$ & 4.5- 5.5 & $\begin{array}{l}\text { - Fresh cheese dairy } \\
\text { - Soft cheese dairy } \\
\text { - Acid caseinery }\end{array}$ & {$[14,15]$} \\
\hline
\end{tabular}

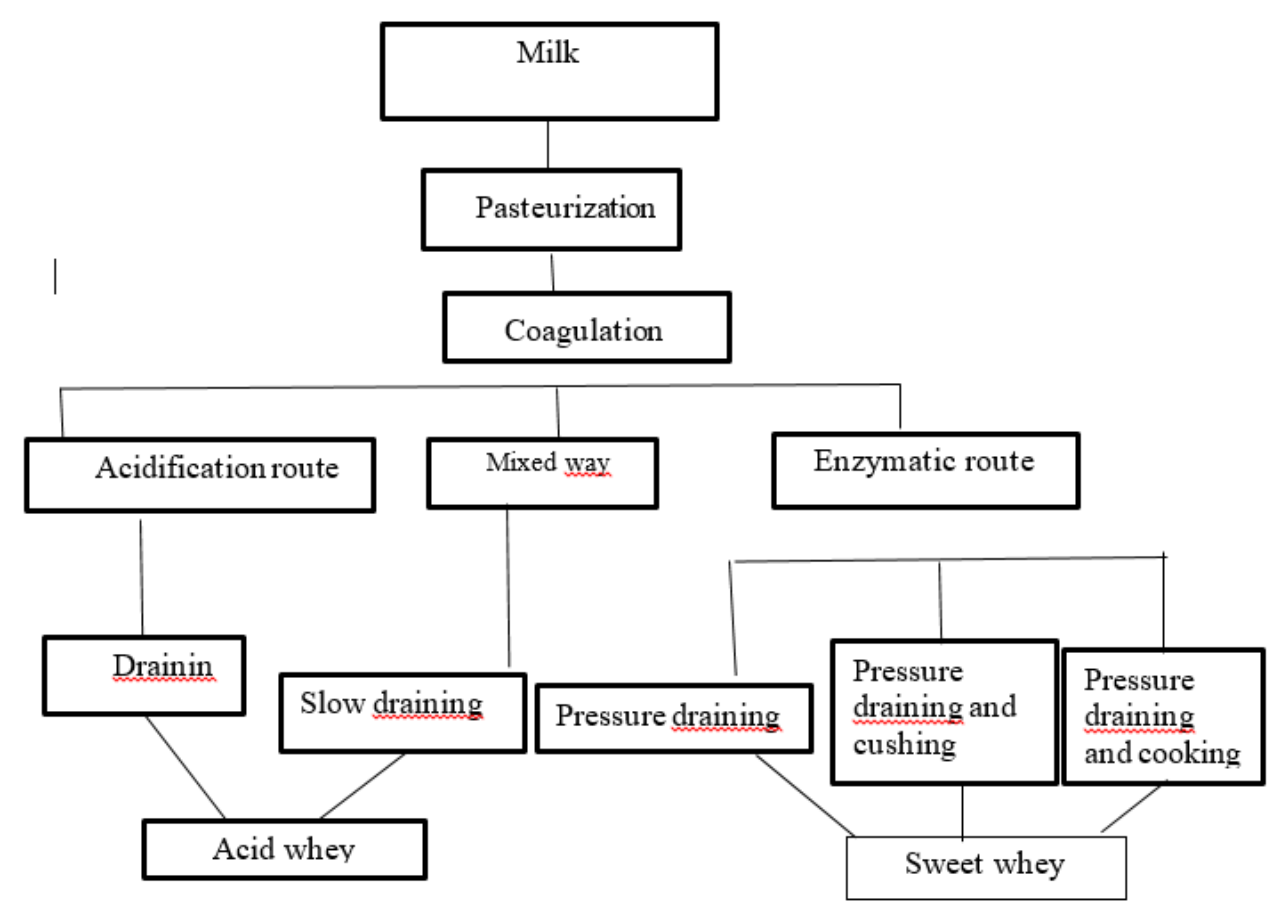

Figure 1 Technological processes of the main types of whey production [13].

\section{Nutritional value of whey}

Depending on the coagulation process and the initial composition of the milk (season, breed of animals, type of feed, etc.), the composition of whey can vary significantly [16].

Whether sweet or sour, whey contains over $90 \%$ of water. It also contains a high lactose content $(75 \%$ of the dry matter), a low fat content, soluble milk proteins (i.e. about $20 \%$ of total milk proteins) and various minerals. It also contains other components, such as citric acid and lactic acid, non-protein nitrogenous materials such as urea and uric acid and group B vitamins, mainly vitamin B1 (thiamine), vitamin B2 (riboflavin) and vitamin B6 (pyridoxine). Generally, acidic whey contains less lactose and more minerals, including phosphorus and calcium. Many authors have determined the composition of these products [17]. Table 2 shows the average compositions of the two categories of whey. Sweet whey has higher protein content than acidic whey due to the acid precipitation of some proteins. The major difference between these two categories of whey is in the levels of lactose and lactic acid. Sweet whey is more easily recoverable industrially than acid whey which poses more difficulties during drying. These problems are partly due to the high mineralization, the low lactose content and the variability of the composition of the acid whey [18]. 
Table 2 Average composition of sweet and sour whey.

\begin{tabular}{|c|c|c|c|}
\hline & Sweet whey (\%) & Acid whey (\%) & References \\
\hline $\mathrm{pH}$ & 6.3 & 4.6 & \multirow[t]{11}{*}{$19,20,21,22$} \\
\hline Water content & 93 & 93.5 & \\
\hline Lactose & 4.77 & 4.71 & \\
\hline Protein & 0.82 & 0.75 & \\
\hline Fat & 0.07 & 0.03 & \\
\hline Lactic acid & 0.15 & 0.55 & \\
\hline Ashes & 0.53 & 0.69 & \\
\hline Calcium & 0.05 & 0.13 & \\
\hline Sodium & 0.07 & 0.06 & \\
\hline Potassium & 0.13 & 0.15 & \\
\hline Phosphorus & 0.06 & 0.09 & \\
\hline
\end{tabular}

\subsection{Whey protein composition}

Proteins are molecules made up of amino acids, which are either synthesized from genes or provided through food. Two major families of proteins enter into the composition of milk; the first is made up of caseins which represent about $80 \%$ of total milk protein. The second family of soluble proteins consists essentially of $\beta$-lactoglobulin ( $\beta$-LG), $\alpha$-lactalbumin $(\alpha$-LA), bovine serum albumin (BSA), immunoglobulins (Ig) and peptone proteinoses [23] (Table 3).

Table 3 Content of protein compounds in whey [24].

\begin{tabular}{|c|c|c|c|}
\hline Protein compounds & Molecular mass (KDa) & Content (\%) & Isoelectric point \\
\hline \multicolumn{4}{|l|}{ Protein } \\
\hline$\beta-L G$ & 18.362 & 50 & 5.2 \\
\hline$\alpha-\mathrm{LA}$ & 14.147 & 22 & $4.5-4.8$ \\
\hline BSA & 69.000 & 5 & $4.7-4.9$ \\
\hline Ig & $150-1000$ & 12 & $5.5-8.3$ \\
\hline Lactoferrin & 80 & $<1$ & $8.4-9$ \\
\hline \multicolumn{4}{|l|}{ Enzymes } \\
\hline Lactoperoxidases & 78 & \multirow{6}{*}{$<1$} & 9.5 \\
\hline Lysozyme & 18 & & 9.5 \\
\hline Alkaline phosphatase & $160-190$ & & $\mathrm{Nd}$ \\
\hline Catalase & 60 & & 5.7 \\
\hline Sulphydryl oxidase & 89 & & $\mathrm{Nd}$ \\
\hline Plasmin & $\mathrm{Nd}$ & & $\mathrm{Nd}$ \\
\hline \multicolumn{4}{|l|}{ Peptide } \\
\hline Protease-peptones & $\mathrm{Nd}$ & $\mathrm{Nd}$ & $\mathrm{Nd}$ \\
\hline Glycomacropeptides & 7 & 10 & $\mathrm{Nd}$ \\
\hline
\end{tabular}

$\mathrm{Nd}$ : Not determined 
Protein is not the most abundant fraction of whey, but it is the most economically and nutritionally interesting which is superior to egg white protein, taken as a reference protein. Table 4 shows their compositions in amino acid. Blactoglobulin ( $\beta$-LG) is the most abundant of whey proteins; it represents approximately 2 to $4 \mathrm{~g} / \mathrm{L}$, which corresponds to $50 \%$ of total whey proteins [25]. B-Lactoglobulin, absent in human milk, has all natural amino acids and contains $58 \%$ of essential amino acids. It presents a dipeptide (Glu-Cys) which can be used for the synthesis of glutathione, very involved in cellular redox reactions, and it can also act as a transporter for vitamin A and vitamin D. Due to its high concentration and its composition, it is the whey protein with the highest nutritional value.

$\alpha$-Lactalbumin also contains all natural amino acids and $57 \%$ of essential amino acids. Stimulation of immune defenses, so-called "anti-cancer" and antiviral properties as well as a bactericidal peptide are characteristic of this protein. Lactoferrin, on the other hand, is a metalloprotein that can bind to two ferric iron atoms and therefore allows its transport and absorption. By acting on the iron level, bovine lactoferrin can have an antibacterial role.

$\alpha$-Lactalbumin is another very interesting functional protein due to its composition rich in tryptophan, which makes it a base for the production of peptides intended for dietetic or nutritional food [16].

Table 4 Essential amino acids (gr / 100gr) [3].

\begin{tabular}{|c|c|c|}
\hline & Whey protein & Caseins \\
\hline Tryptophan & 1.38 & 1.22 \\
\hline Lysine & 1.09 & 8.81 \\
\hline Methionine & 1.95 & 3.07 \\
\hline Cysteine & 1.35 & 0.57 \\
\hline Leucine & 7.09 & 9.8 \\
\hline Isoleucine & 4.06 & 4.8 \\
\hline Phenylalanine & 3.47 & 5.18 \\
\hline Valine & 5.54 & 3.55 \\
\hline Threonine & 5.03 & 4.7 \\
\hline
\end{tabular}

\subsection{Lactose composition of whey}

Lactose is the major compound in the dry extract of whey. It is a diholoside, composed of two oses, galactose and glucose, linked by a $\beta 1-4$ bond. Lactose plays a role in the absorption of calcium and other minerals such as copper and zinc, especially during infancy [26]. In addition, if it is not digested in the small intestine, lactose can be used by the gut microbiota (the population of microorganisms that live in the digestive tract) as a nutrient (prebiotic). Lactose and other sugars in milk also promote the growth of bifidobacteria in the gut and may play a long-term role in combating the aging-related decline of certain immune functions.

\subsection{Composition of whey in minerals and vitamins}

The main mineral salts present in whey are chlorides, phosphates, citrates of calcium, sodium, magnesium and potassium (Figure 2). It should be noted that the characteristics of milk vary depending on the species, breeds, environment, diet and physiological and health conditions of the animals. However, it is estimated that on average, a liter of milk contains 8.5 to $9 \mathrm{~g}$ of mineral salts, including $1.2 \mathrm{~g}$ of calcium and $0.95 \mathrm{~g}$ of phosphate. After completion of the milk processing, the sweet whey contain 2.5 to $4.7 \mathrm{~g}$ of minerals per liter of whey and the sour whey contain 4.3 to $7.2 \mathrm{~g}$. For example, whey contains an average of $4.8 \mathrm{~g}$ of mineral salts, a reduction of about $50 \%$ from the initial milk content [27]. 


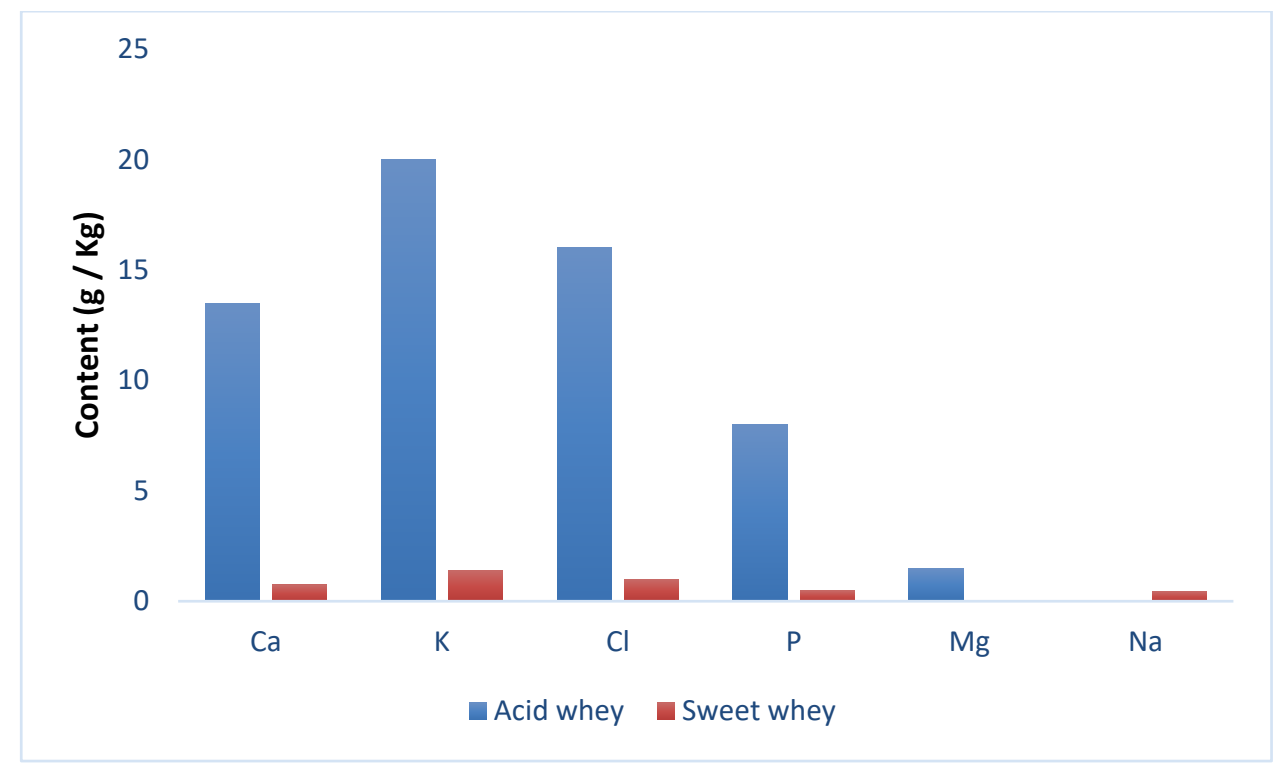

Figure 2 Composition of mineral salts for $1 \mathrm{~kg}$ of whey [14].

Whey also contains essential vitamins (Figure 3) for our body and more specifically vitamins B1, B2, B3, B5, B12, B6, B9 and C, some of which can be used in the pharmaceutical or food industry.

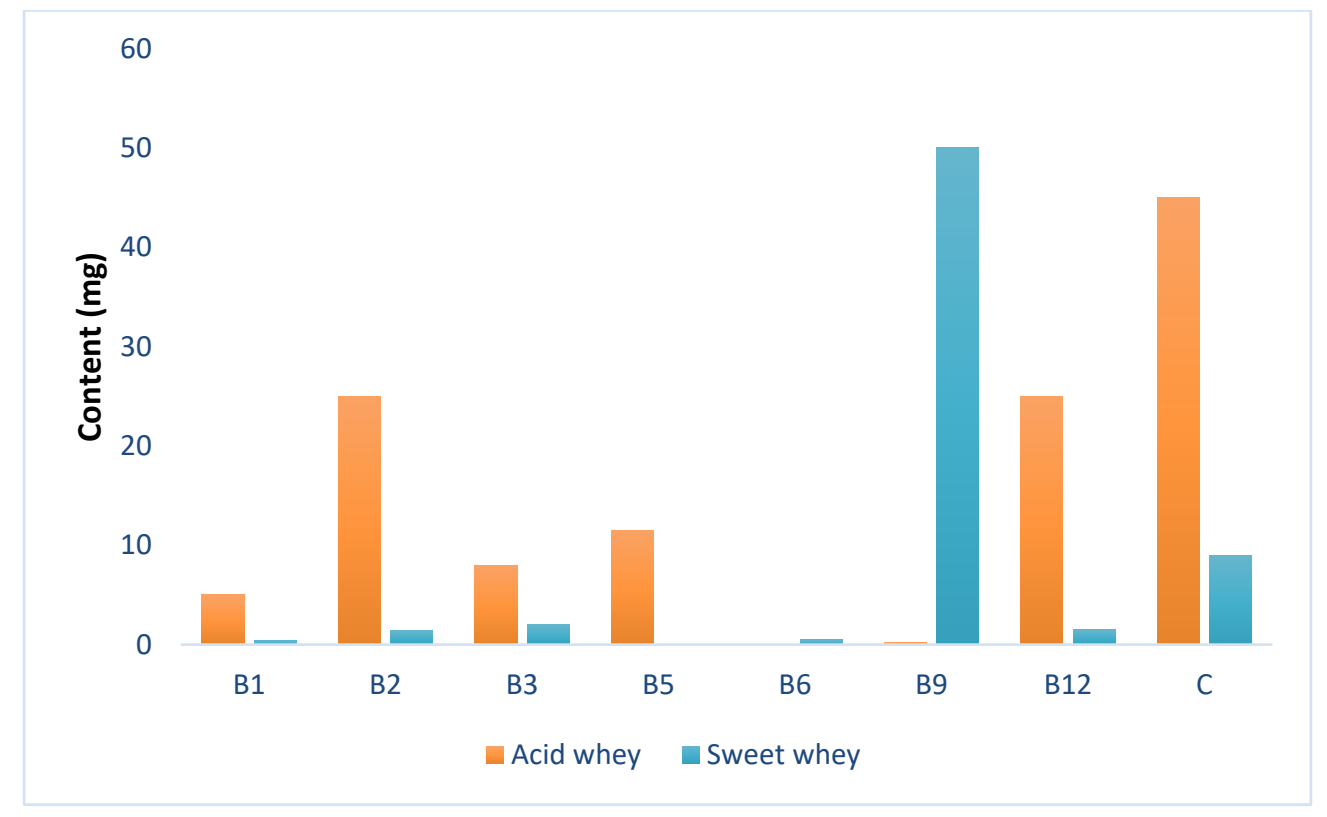

Figure 3 Vitamin composition for $1 \mathrm{~kg}$ of whey [14].

\section{Whey recycling methods}

\subsection{Importance and way of whey valorization}

In addition to its use in agriculture, especially for pig feed, whey (whole or its constituents) is also used in the food and pharmaceutical industry. There are several methods of processing and upgrading whey. These techniques allow obtaining numerous products which can be used in different fields. 


\subsubsection{Indirect way of whey valorization}

Use of lactose from whey

Lactose is extracted by crystallization. Enzymatic or chemical treatments are also applied in order to modify its structure and its technological or biological properties [28]. This milk sugar is used as a pharmaceutical or food ingredient. Lactose recovered from whey can be used directly or after processing, which is of great interest to the food industry since it has a high nutritional value and many properties. On the one hand, it is used in several food preparations for children and animals. On the other hand, it is considered to be a pure soluble sugar with low sweetening power, capable of improving the texture of foods. In this sense, its use in powdered food preparations or tablets is relatively recurrent. Likewise, it is often a component of dietetic products since its addition would tend to reduce the fat content of certain products such as chocolate drinks, while maintaining their qualities. Thus, the final products obtained will therefore be less rich in calories. It can also be used to reduce the intensity of the sweet flavor, thus its role as a sweetener is exploited [29]. Moreover, this sugar crystallizes easily and therefore allows considering its incorporation in confectionery or other products incorporating chocolate. This crystallization plays a fundamental role in the appearance of the final product. For the preparation of powder products, it can facilitate drying and dispersing operations. It also acts as a stabilizer for dyes [11]. Lactose can be used directly, without transformation, as an excipient in the pharmaceutical field and more particularly in that of galenic pharmacy (drug formulation). An excipient is an inert element which gives greater stability to the active substances. It also has physical properties that impart their shape, solubility, correct and targeted dissolution to tablets. The use of lactose as an excipient is economically advantageous because it is inexpensive, compatible with a large number of active substances, very stable and has excellent solubility with water. Lactose is used to obtain lactulose by isomerization, which is frequently used as a laxative to treat constipation and diseases such as hepatic encephalopathy (cirrhosis of the liver). Lactose is used in the production of solvents, vitamins, methane polysaccharides, enzymes, amino and organic acids and many other compounds from whey lactose [30]. All the whey fermentation processes show that the lactic acid production system is one of the most advantageous (Figure4).

Whey by its biochemical composition has interesting properties as fermentation medium for several microorganisms that assimilate lactose as a source of carbon and energy such as Lactobacillus casei for the production of lactic acid or Penicillium camemberti for proteases production [30].

From lactose, there can also be obtained succinic acid $\left(\mathrm{C}_{4} \mathrm{H}_{6} \mathrm{O}_{4}\right)$. It is currently produced mainly by the petrochemical industry, but it is increasingly produced by biotechnological processes, in particular by the bacterial fermentation of lactose [31].

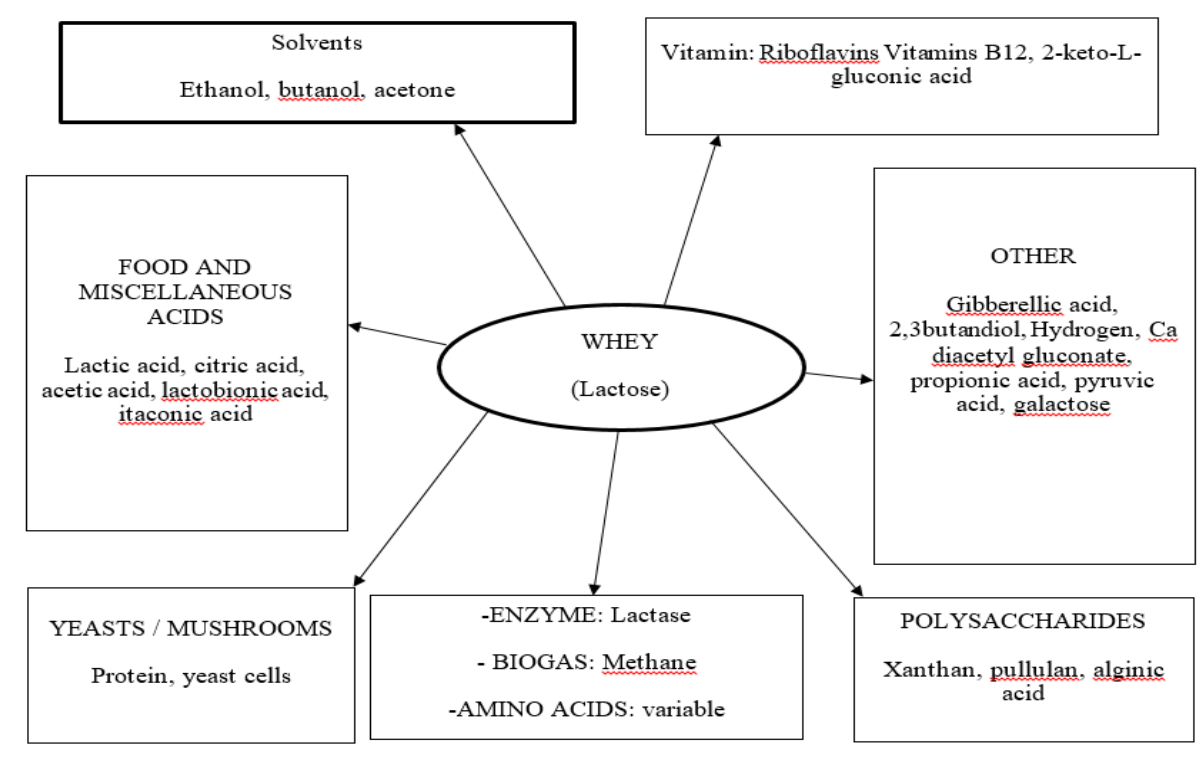

Figure 4 Valorization of whey through lactose [32]. 


\section{Use of whey protein}

Whey proteins pass through the stomach faster than caseins. In the stomach, the soluble fraction of milk proteins is evacuated rapidly while the caseins precipitate on contact with the acidic $\mathrm{pH}$ of the medium, forming a dense protein system [33]. Thus, whey proteins, which are rapidly emptied from the stomach, can be regarded as "fast" proteins, causing a rapid but short-lived rise in the amino acid content of the blood plasma (or hyperaminoacidemia) and a concomitant stimulation of protein synthesis [33]. On the contrary, the caseins which are absorbed gradually are qualified as "slow" proteins. Whey proteins are recovered in the form of concentrates (whey protein concentrates) or isolates (whey protein isolates) using specific separation processes like ultrafiltration, diafiltration, electrodialysis and ion exchange chromatography. These processes allow the concentration of the whey while retaining its nutritional qualities [34].

Whey protein concentrates are generally produced in powder form with protein content, expressed on a dry matter basis, of between 30 and $90 \%$. As for whey protein isolates, which come in powder form, they contain on average 90 to 95\% protein and contain a high level of immunoglobulin. They are lactose-free and contain virtually no carbohydrate or fat [33]. Serum proteins are used in animal feed and are also exploited in the food industry for their nutritional properties and their physicochemical and structural characteristics allowing them to have excellent capacities for hydration, for the formation of protein systems and adsorption at interfaces [35]. Serum proteins are used in the composition of many food formulations, in particular in preparations intended for infant nutrition, dairy products, biscuits, confectionery, drinks, dietetic products, cold meats, pastry, sauces, etc. They are also used in the development of yeasts and serve as food supplements in certain sports products. The arrival of whey protein concentrates (sometimes called whey) has been a revolution in the world of fitness and bodybuilding. Their high protein content and low fat and calorie content make them a great supplement before and after exercise. The proteins contained in whey are credited with a major role in the reconstruction of muscle fibers that have suffered micro-tears during training [36]. Absorbing about $20 \mathrm{~g}$ of protein during, or immediately after, exercise is sufficient to maximize post-workout muscle protein synthesis. The stimulation of muscle anabolism seems more marked in a recovery situation after intense muscular exercise and after ingestion of essential amino acids (in particular leucine)[33].

\subsubsection{Direct way of valuing whey in human food}

One of the most widespread ways of whey valorization in developed countries is the production of cheese. Ricotta and Corsican brocciu are the most famous cheeses obtained from whey. Ricotta of Italian origin, means "annealed", because in the past the cheesemaker used to anneal the whey from his cheese making, in order to recover the serum proteins that had not been captured during the cheese making [37]. It was a way of not wasting anything and of recovering almost all of the proteins contained in the milk. By virtue of its composition, the cheeses obtained from whey are therefore a lean cheese, rich in protein, with a creamy texture and a little grainy. It is generally used in addition to ready meals [38].

\section{Conclusion}

Whey represents an interesting source of active compounds and specific nutrients, exhibiting incomparable properties, both nutritionally and techno-functionally. Thus, this by-product is widely used indirectly for the formulation of food and pharmaceutical products. However, it remains to be better developed and to look for other ways of direct valorization in human food.

\section{Compliance with ethical standards}

\section{Acknowledgments}

The authors thank all the collaborators from various laboratories of the national universities of Benin who contributed to the writing of this article.

\section{Disclosure of conflict of interest}

The authors agree no conflict of interest. 


\section{References}

[1] FAOSTAT. 2016 Production Crops Africa.

[2] Abdili N. 2009 Valorisation du lactose en acide succinique par fermentation bactérienne. Mémoire présenté à la faculté des études supérieures de l’Université de Laval dans le cadre du programme de maîtrise en microbiologie agricole. Faculté des sciences de l'agriculture et de l'alimentation. Université de Québec.

[3] Moletta R. 2002 Gestion des problèmes environnementaux dans les IAA. Paris Tech et Doc p 600.

[4] Agnès N. 1986 Production de Protéines à partir de Lactosérum Brut. Thèse de 3ème cycle, Université de Lyon, p.378.

[5] Nikolaou E, Tzanetakis N, Litopoulou-Tzanetaki, E, and Robinson RK. Changes in the microbiological and chemical characteristics of an artisanal, low-fat cheese made from raw ovine milk during ripening. International Journal of Dairy Technology, 2002; 55(1), 12-17.

[6] De Wit JN. Structure and functional behaviour of whey proteins. Netherlands Milk and Dairy Journal, 1981; 4, 617-623.

[7] Prazeres AR, Carvalho, F and Rivas J. Cheese whey management. A review Journal of environmental management, 2012; 110: 48-68.

[8] Linden G and Lorient D. 1994 valorisation alimentaire de la Production agricole. Biochimie agro industrielle. Masson Paris Milan Barcelone.

[9] De la fuente MAY, Hemar M, Tamehana PA, Munro H. Process Induced changes in whey proteins during the manufacture of whey protein Concentrates. International dairy journal, 2002; 12, 361-369.

[10] Violleau V. valorisation du lactosérum par électrodialyse. Thèse de doctorat. Université de Montpellier, 1999; p.336.

[11] Chen GQ, Eschbach FI, Weeks M, Gras SL and Kentish SE. Removal of lactic acid from acid whey using electrodialysis. Separation and Purification Technology, 2016; 158, 230-237.

[12] Chandrapala J, Duke MC, Gray SR, Zisu B, Weeks M, Palmer M, and Vasiljevic, T. Properties of acid whey as a function of $\mathrm{pH}$ and temperature. Journal of Dairy Science, 2015; 98(7):4352-4363.

[13] Sottiez P. Produit dérivés des fabrications fromagères, lait et produits laitiers, Ed. Lavoisier, Paris, 1990; 2: 357392.

[14] Adrian J, Bourlier G, Sabel A. Composition minérale du lactosérum. Influence des facteurs technologiques, saisonniers et géographiques. Le Lait, INRA, 1991; 60:447-457.

[15] Gallardo-Escamilla F. J, Kelly AL, and Delahunty CM. Sensory characteristics and related volatile flavor compound profiles of different types of whey. Journal of Dairy Science, 2005; 88(8):2689-2699.

[16] Schuck P, Bouhallab S, Durupt D, Vareille P and Humbert JP. Séchage des lactosérums et dérivés: rôle du lactose et de la dynamique de l'eau. Le lait INRA, 2004; 84 (3):243-268

[17] Sindayikengera, S, and Xia WS. Nutritional evaluation of caseins and whey proteins and their hydrolysates from Protamex. Journal of Zhejiang University Science, 2006; 7(2):90-98.

[18] Karwowska M and Kononiuk A. Addition of acid whey improves organic dry-fermented sausage without nitrite production and its nutritional value. International Journal of Food Science \& Technology, 2018; 53(1):246-253.

[19] Linden G et Lorient D. Biochimie agro industrielle; valorisation alimentaire de la Production agricole. Masson Paris Milan Barcelone. 1994

[20] Sodini I, Morin P, Olabi A and Jiménez-Flores R. Compositional and functional properties of buttermilk: A comparison between sweet, sour, and whey buttermilk. Journal of Dairy Science, 2006; 89(2):525-536.

[21] Božanić R, Barukčić I and Lisak K. Possibilities of whey utilisation. Austin Journal of Nutrition and Food Sciences, 2014; 2(7):7-17.

[22] Pesta G, Meyer-Pittroff R and Russ W. Utilization of whey: Utilization of by-products and treatment of waste in the food industry. Springer, Boston, MA, p.207. 2007

[23] Smithers GW. Whey and whey proteins from 'gutter-to-gold. International Dairy Journal, 2008; 18(7):695-704. 
[24] De wit, JN. the use of whey proteins products, in developments in dairy chemistry. Elsevier applied science, 1989; 4:323-329.

[25] Roufik S, Gauthier SF and Turgeon SL. Physicochemical characterization and in vitro digestibility of $\beta$ lactoglobulin/ $\beta$ - Lg f142-148 complexes. International dairy journal, 2007; 17(5), 471-480.

[26] Amaretti A, Tamburini E, Bernardi T, Pompei A, Zanoni S, Vaccari G and Rossi M. Substrate preference of Bifidobacterium adolescentis MB 239: compared growth on single and mixed carbohydrates. Applied microbiology and biotechnology, 2006; 73(3):654-662.

[27] Macwan SR, Dabhi BK, Parmar SC and Aparnathi KD. Whey and its utilization. International Journal of Current Microbiology and Applied Sciences, 2016; 5(8):134-155.

[28] de Souza, RR, Bergamasco R, da Costa SC, Feng X, Faria SHB and Gimenes ML. Recovery and purification of lactose from whey. Chemical Engineering and Processing, 2010; 49(11):1137-1143.

[29] Arora S, Shendurse AM, Sharma V, Wadhwa BK and Singh AK. Assessment of stability of binary sweetener blend (aspartame $\mathrm{x}$ acesulfame-K) during storage in whey lemon beverage. Journal of food science and technology, 2013; 50(4):770-776.

[30] Albertini B, Cavallari C, Passerini N, González-Rodríguez ML and Rodriguez L. Evaluation of $\beta$-lactose, PVP K12 and PVP K90 as excipients to prepare piroxicam granules using two wet granulation techniques. European journal of pharmaceutics and biopharmaceutics, 2003; 56(3):479-487.

[31] Song H and Lee SY. Production of succinic acid by bacterial fermentation. Enzyme and microbial technology, 2006; 39(3):352-361.

[32] Morabito D. Production d'acide lactique par Lactobacillus casei sur lactoserum: études cinétiques, modélisation et simulation de procédé intégré. Alimentation et Nutrition. Thèse de doctorat, Institut National Polytechnique de Lorraine, 1994; p.316.

[33] Mahé S. Nitrogen movements in the upper jejunum lumen in humans fed low amounts of casein or betalactoglobulin. Gastroentérologie clinique et biologique, 1995; 19(1):20-26.

[34] Kebbouche S. Valorisation du Lactosérum par la Production de Protéines d. Organismes Unicellulaires à partir de Levures Locales. 1998

[35] Montet D, Ratomahenina R, Laborbe JM, Pina M, Graille J and Galzy P. 1985 Production de protéines d'organismes unicellulaires à partir de pâtes de neutralisation d'origine industrielle.

[36] van Loon L. J and Gibala MJ. Dietary protein to support muscle hypertrophy. Sports Nutrition: More Than Just Calories-Triggers for Adaptation, 2011; 69:79-96.

[37] Froc J. Les traditions fromagères en France. Beau livre (broché), Quae: Format, p. 240. 2007

[38] Lacroix M. 2008. Variations qualitatives \& quantitatives de l'apport en protéines laitières chez l'animal \& l'homme: implications métaboliques. Doctoral dissertation, Institut national agronomique Paris-Grignon, p.224 